\title{
Undiagnosed arterial hypertension in the inhabitants of Jaworzno
}

\section{Nierozpoznane nadciśnienie tętnicze u mieszkańców Jaworzna}

\author{
Tomasz Jerzy Irzyniec ${ }^{1,2}$, Jolanta Prusek', Beata Głośnicka', Monika Boryń², Jerzy Bieńkowski \\ 'Department of Health Promotion and Community Nursing, Faculty of Health Sciences, Medical University of Silesia, Katowice, Poland \\ ${ }^{2}$ Department of Nephrology, Hospital of the Ministry of Interior Affairs, Katowice, Poland
}

\begin{abstract}
Summary
Background The data of the WOBASZ (National Multicentre Health Survey in Poland) revealed considerable regional differences regarding the prevalence of arterial hypertension. The differences between Polish Provinces might be due to undiagnosed cases of hypertension. The aim of the study was to determine the proportion of Jaworzno inhabitants with undiagnosed hypertension. Another aim was to define the characteristics of this group.

Material and methods Letters of invitation were sent to 1.500 Jaworzno inhabitants aged 35-55 years. These potential study participants received medical care from their family doctors but had not been treated for cardiovascular diseases. The group comprised 780 participants ( 513 women and 267 men aged $46.7 \pm 4.3$ and $45.6 \pm 4$ years). Blood pressure, BMI, lipidogram and glucose levels were obtained as well as data on cigarette smoking, physical activity and family history of hypertension.

Results Arterial hypertension was diagnosed in 107 women (21\%) and 128 men (47.9\%). The proportion of obese or overweight women and men was $76.6 \%$ and $79.7 \%$, respectively and was higher than the respective values $(43 \%$ and 51.8\%) in normotensives. Abnormalities of lipid metabolism were also more frequent in hypertensive participants. The proportions of hypertensive women and men with at least one abnormal lipid parameter were comparable and amounted to $83.2 \%$ and $85.2 \%$, respectively. These values were significantly higher than in normotensive female $(37.8 \%)$ and male $(42.4 \%)$ participants.

Conclusion Even $48 \%$ of men and 20\% of women aged 35-55 years of Jaworzno's non-treated population may have undiagnosed arterial hypertension; the majority of them are obese or overweight.

key words: arterial hypertension, obesity, statistic, epidemiology

Arterial Hypertens. 2015, vol. 19, no. 4, pages: 194-199

DOI: $10.5603 / A H .2015 .0024$
\end{abstract}

\section{Background}

Arterial hypertension is a disease of multifactorial and complex pathogenesis characterized by persistent or periodic elevation of systolic and/or diastolic blood pressure, which leads to vascular abnormali- ties and organ damage [1]. Hypertension occurs as a consequence of interplay of genetic alterations and environmental factors.

The epidemiology of arterial hypertension has been studied for over 50 years now. First population studies on cardiovascular system diseases concerned

\footnotetext{
Address for correspondence: Tomasz Irzyniec, MD, PhD Department of Health Promotion and Community Nursing Głowackiego 10, 40-052 Katowice, Poland tel.: +48 32 782-72-21; fax: +48 32 782-73-00 e-mail: tirzyniec@sum.edu.pl
} 
precisely hypertension. The results of epidemiological studies seem to confirm that high blood pressure is the price many people have to pay for modern life [2]. Contemporary humans have adopted a risky lifestyle including overeating, high salt and fat intake and a decrease in physical activity leading to a positive energy balance and related health outcomes. The influence of nutrition on blood pressure was confirmed by the effectiveness of the Rice Diet Program (extremely low sodium and increased potassium content), commonly applied to treat arterial hypertension [3]. Alcohol, despite its potentially protective effect on the heart, contributes to hypertension epidemic $[4,5]$. Cigarette smoking adversely affects haemodynamics, lipid metabolism and vascular endothelium. Smoking 20 cigarettes per day may cause persistent elevation of blood pressure [6]. Physical effort also influences blood pressure. Aerobic exercises significantly lower systolic and diastolic pressure both in normotensive and hypertensive people [7].

Research centres focused on the epidemiology of risk factors for heart disease carried out national epidemiological studies based on a representative sampling approach. There were four major projects: - the NATPOL PLUS Survey conducted in 2002

(3,051 adult participants aged 18 to 94 years) [8];

- the WOBASZ Project conducted in the years 2003-2006 (13.545 adult participants aged 20 to 74 years) [9];

- the POLSENIOR Project conducted in the years 2007-2010 (the study population comprised 4.949 participants aged 65 to 100 years);

- the NATPOL 2011 Survey performed in 2011 (2.404 adult participants aged 18 to79 years).

The aim of the above projects was: 1 . to assess the prevalence of arterial hypertension and the effectiveness of hypertension treatment in Poland, 2. to increase the awareness of one's own blood pressure among Polish adults and 3. to determine the relationship between arterial hypertension and risk factors for cardiovascular disease [10].

The WOBASZ Study comprised a representative sample of the Polish population aged 20 to 74 years; $42 \%$ of 6.977 men and $33 \%$ of 7.792 women had arterial hypertension. However, regional differences were observed regarding the prevalence of blood pressure elevation. Silesia and Greater Poland Provinces had higher proportions of hypertensive inhabitants compared to Lodz and Lublin Provinces. The differences might be due to undiagnosed hypertension cases?

Jaworzno is an industrial city with a population of 90.000, situated at the border of Silesia and Lesser Poland Provinces, which differ regarding the pro- portion of inhabitants with arterial hypertension. Jaworzno belongs to the Province of Silesia, i.e., the Province with the highest proportion of hypertensive men and women while the proportion in Lesser Poland Province is much lower.

The aim of the present study was to determine the following:

- the proportion of inhabitants with blood pressure elevation, which, according to ESH/ESC criteria, justifies the diagnosis of arterial hypertension in the so far untreated population of the city of Jaworzno;

— the characteristics of this group.

\section{Material and methods}

Letters of invitation were sent to 1.500 Jaworzno inhabitants aged 35 to 55 years. These potential study participants received medical care from their family doctors but had not been treated for cardiovascular diseases including arterial hypertension. Of those, 780 persons agreed to participate and among them a subgroup of 513 women and another subgroup of 267 men, aged $46.7 \pm 4.3$ and 45.6 \pm 4.0 years (mean $\pm S D$ ), respectively. A Preventive Care Checklist Form was used to determine the global and individual risk for cardiovascular disease including hypertension. Apart from personal data, the checklist comprised information on smoking (a smoker was defined as a person who regularly smokes more than 1 cigarette a day), physical activity (e.g. walking, jogging, cycling, swimming — at least three 30-minute sessions a week) and a positive family history (coronary heart disease, arterial hypertension or other atherosclerotic vascular disease in parents or siblings). During each patient's appointment, body weight and height were measured using digital scales and a stadiometer; Body Mass Index was then calculated. Blood pressure was taken three times with a standard sphygmomanometer: the first measurement was performed at the participant's arrival to the clinic, and the last one 15 minutes later. The mean value of the second and third measurements was then calculated. According to the $2013 \mathrm{ESH} / \mathrm{ESC}$ Guidelines for the management of arterial hypertension, the latter was diagnosed when the participant's systolic and diastolic blood pressure were $\geq 140 \mathrm{~mm} \mathrm{Hg}$ and/or $\geq$ $90 \mathrm{~mm} \mathrm{Hg}$, respectively [11]. Other parameters were determined based on laboratory investigations. The following findings were considered abnormal: total cholesterol $\geq 200 \mathrm{mg} / \mathrm{dL}, \mathrm{LDL} \geq 130 \mathrm{mg} / \mathrm{dL}, \mathrm{HDL}$ $\geq 40 \mathrm{mg} / \mathrm{dL}, \mathrm{TG} \geq 180 \mathrm{mg} / \mathrm{dL}$ (in diabetic par- 
Table I. Blood pressure (BP), BMI and total cholesterol (TC), high (HDL) and low (LDL) density lipoprotein, triglycerides (TG) and glucose levels in 513 female inhabitants of Jaworzno, so far untreated for cardiovascular diseases and hypertension. (mean \pm SD)

Tabela I. Ciśnienie tętnicze (BP), BMI, stężenie cholesterolu całkowitego (TC), lipoprotein dużej (HDL) i małej (LDL) gęstości, trójglicerydów (TG) i glukozy u 513 mieszkanek Jaworzna, do tej pory nie leczonych z powodu chorób układu sercowo-naczyniowego i nadciśnienia tętniczego (wartości średnie $\pm \mathrm{SD}$ ).

\begin{tabular}{|c|c|c|c|c|c|c|c|c|}
\hline Women & $\begin{array}{c}\text { BP } \\
\text { systolic } \\
{[\mathrm{mm} \mathrm{Hg}]}\end{array}$ & $\begin{array}{c}\text { BP } \\
\text { diastolic } \\
{[\mathrm{mm} \mathrm{Hg}]}\end{array}$ & $\begin{array}{c}\text { BMI } \\
{\left[\mathrm{kg} / \mathrm{m}^{2}\right]}\end{array}$ & $\begin{array}{c}\mathrm{TC} \\
{[\mathrm{mg} / \mathrm{dl}]}\end{array}$ & $\begin{array}{c}\mathrm{HDL} \\
{[\mathrm{mg} / \mathrm{dl}]}\end{array}$ & $\begin{array}{c}\text { LDL } \\
{[\mathrm{mg} / \mathrm{dl}]}\end{array}$ & $\begin{array}{c}\text { TG } \\
{[\mathrm{mg} / \mathrm{dl}]}\end{array}$ & $\begin{array}{l}\text { Glucose } \\
\text { [mg/dl] }\end{array}$ \\
\hline $\begin{array}{l}\text { Hypertensive } \\
(\mathrm{n}=107)\end{array}$ & $151 \pm 19 \#$ & $101 \pm 8 \#$ & $28 \pm 6^{\wedge}$ & $229 \pm 36$ & $60 \pm 11$ & $141 \pm 30$ & $141 \pm 76$ & $100 \pm 27$ \\
\hline $\begin{array}{l}\text { Normotensive } \\
(\mathrm{n}=406)\end{array}$ & $116 \pm 13$ & $78 \pm 9$ & $26 \pm 7$ & $226 \pm 43$ & $64 \pm 15$ & $142 \pm 38$ & $142 \pm 38$ & $93 \pm 22$ \\
\hline
\end{tabular}

Table II. Blood pressure (BP), BMI and total cholesterol (TC), high (HDL) and low (LDL) density lipoprotein, triglycerides (TG) and glucose levels in 267 male inhabitants of Jaworzno, so far untreated for cardiovascular diseases and hypertension (mean \pm SD)

Tabela II. Ciśnienie tętnicze (BP), BMI, stężenie cholesterolu całkowitego (TC), lipoprotein dużej (HDL) i małej (LDL) gęstości, trójglicerydów (TG) i glukozy u 267 mieszkańców płci męskiej Jaworzna, do tej pory nie leczonych z powodu chorób układu sercowo-naczyniowego i nadciśnienia tętniczego (wartości średnie \pm SD)

\begin{tabular}{l|c|c|c|c|c|c|c|c}
\hline Men & $\begin{array}{c}\text { BP } \\
\text { systolic } \\
{[\mathrm{mm} \mathrm{Hg}]}\end{array}$ & $\begin{array}{c}\text { BP } \\
\text { diastolic } \\
{[\mathrm{mm} \mathrm{Hg}]}\end{array}$ & $\begin{array}{c}\text { BMI } \\
{\left[\mathrm{kg} / \mathrm{m}^{2}\right]}\end{array}$ & $\begin{array}{c}\text { TC } \\
{[\mathrm{mg} / \mathrm{dl}]}\end{array}$ & $\begin{array}{c}\text { HDL } \\
{[\mathrm{mg} / \mathrm{dl}]}\end{array}$ & $\begin{array}{c}\text { LDL } \\
{[\mathrm{mg} / \mathrm{dl}]}\end{array}$ & TG [mg/dl] & $\begin{array}{c}\text { Glucose } \\
{[\mathrm{mg} / \mathrm{dl}]}\end{array}$ \\
\hline $\begin{array}{l}\text { Hypertensive } \\
(\mathrm{n}=128)\end{array}$ & $154 \pm 16 \#$ & $101 \pm 9 \#$ & $29 \pm 6^{\wedge}$ & $237 \pm 54^{\wedge}$ & $54 \pm 15$ & $151 \pm 38$ & $183 \pm 143^{\wedge}$ & $106 \pm 31$ \\
\hline $\begin{array}{l}\text { Normotensive } \\
(\mathrm{n}=139)\end{array}$ & $121 \pm 12$ & $80 \pm 8$ & $26 \pm 4$ & $225 \pm 44$ & $52 \pm 13$ & $142 \pm 37$ & $153 \pm 90$ & $99 \pm 31$ \\
\hline
\end{tabular}

$\# p<0.001 ; \wedge p<0.05$ vs normotensive

ticipants $\mathrm{TG} \geq 150 \mathrm{mg} / \mathrm{dL}$ ) and fasting glycaemia $\geq 126 \mathrm{mg} / \mathrm{dL}$. Mean values and standard deviations were calculated for the female and male subgroups. The proportion of the whole study group (i.e., 780 participants) with pathological findings was also determined.

Another part of the study was the assessment of cardiovascular disease risk based on the SCORE algorithm (Systematic Coronary Risk Evaluation). The global risk of a cardiovascular event was assessed. The study participants were allocated to one of the following risk groups:

- I. low risk: study participants with no risk factors other than age and sex;

- II. moderate risk: $\leq 3$ risk factors but no diabetes, ischaemic heart disease or other cardiovascular disease;

- III. high risk: 4-5 risk factors other than age and sex but no diabetes, ischemic heart disease or other cardiovascular disease;

— IV. very high risk: > 3 risk factors plus diabetes, ischaemic heart disease or other cardiovascular disease.

As already mentioned, the study group was divided into 1) the female and male subgroups and 2) hypertensive and non-hypertensive participants.
The Mann-Whitney U-test was used for a statistical comparison of the means. The frequency of the occurrence of a particular event was analysed with the test of equality of two structure coefficients. The level of significance was set at $\alpha=0.05$.

\section{Results}

Arterial hypertension ( $\geq 140 / 90 \mathrm{~mm} \mathrm{Hg}$ ) was diagnosed in 235 out of 780 participants, i.e., in 107 of 513 women (20.9\%) and 128 of 267 men (47.9\%). The mean values of blood pressure, body mass index, lipid metabolism and glucose parameters are presented in Tables I and II.

\section{BMI}

As shown in Tables I and II, both women and men with arterial hypertension had a significantly higher BMI compared to the normotensive participants. Also, $76.6 \%$ and $79.7 \%$ of the hypertensive women and men, respectively, were obese or overweight $\left(\mathrm{BMI} \geq 25 \mathrm{~kg} / \mathrm{m}^{2}\right)$. The proportions were significantly higher than the respective values in normotensive female and male participants, i.e., $43 \%$ and $51.3 \%$ $(\mathrm{p}=0.003$ and $\mathrm{p}=0.004$ respectively). 


\section{Lipidogram}

Tables I and II indicate that, contrary to hypertensive women, men with arterial hypertension exhibited significantly higher lipid metabolism parameters compared to their normotensive counterparts. The proportions of hypertensive women and men with at least one abnormal lipid metabolism parameter were comparable and amounted to $83.2 \%$ and $85.2 \%$, respectively. These values were significantly higher than in normotensive female $(37.8 \%)$ and male $(42.4 \%)$ participants; $\mathrm{p}<0.001$.

\section{Glycaemia}

Abnormal glucose concentrations were seen in 7.5\% and $20.3 \%$ of the hypertensive women and men, respectively. The respective values for normotensive female and male participants were $2 \%$ and $3.6 \%$. Individuals with hyperglycaemia did not realize they suffered from diabetes.

\section{Cigarette smoking}

One hundred and sixty-six women (32.4\%) and one hundred and seventeen men $(43.8 \%)$ declared they were current smokers. Among the hypertensive women and men the respective values were $30.8 \%$ and $46.1 \%(\mathrm{p}<0.001)$.

\section{Family history}

The overall proportion of a positive family history among the hypertensive study population was $66 \%$ (65.4 and $66.4 \%$ of the hypertensive women and men, respectively). In the normotensive population the proportion of a positive family history was $55 \%$ (54.2 and $57 \%$ of the normotensive women and men, respectively).

\section{Physical activity}

The proportions of men and women declaring engagement in physical activity were comparable among the female and male study participants. High levels of physical activity were declared by $29.6 \%$ of the hypertensive men and $22.4 \%$ of the hypertensive women. In the normotensive group, the respective proportions were higher and amounted to 38.6 and $37.8 \%$.

\section{Risk for cardiovascular disease}

The proportion of individuals meeting group III and IV criteria for cardiovascular disease was significantly higher among hypertensive participants. The proportion of hypertensive women qualifying for groups III and IV was 53.3\%; among normotensive female participants the proportion was $16 \%(\mathrm{p}<0.001)$. The respective values for men were 64.1 vs $23.2 \%$ $(\mathrm{p}<0.001)$.

\section{Result summary}

Among 780 untreated inhabitants of Jaworzno, onefifth of 513 women and half of 267 men were diagnosed with arterial hypertension. The proportion of individuals with obesity or overweight and lipid metabolism disturbances was significantly higher than among the normotensive study participants. The subgroup of hypertensive men comprised significantly higher proportions of smokers and individuals with significantly higher parameters of glucose and lipid metabolism; the difference between hypertensive and normotensive female participants was not so clearcut. The hypertensive and normotensive subgroups did not differ significantly regarding the proportion of individuals with sufficient levels of physical activity (which was, in fact, low in all subgroups), and participants with a positive family history of hypertension. Over half of the women and men with untreated arterial hypertension were classified as having a high or very high risk of cardiovascular disease (group III or IV).

\section{Discussion}

As mentioned in the Background section of this paper, the results of Polish research indicate considerable regional differences in the proportion of people suffering from undiagnosed and hence untreated arterial hypertension. Based on our study, it can be assumed that 35- to 55-year-old population of Jaworzno might comprise approximately $30 \%$ individuals ( $48 \%$ of men and $21 \%$ of women) with undiagnosed arterial hypertension who do not receive treatment being at a higher risk of developing hypertension-related complications. Therefore campaigns to increase public awareness of hypertension are needed including recommendations of home blood pressure measurement and primary prevention of hypertension. According to current guidelines, blood pressure screening should be performed in all adults at least once a year, regardless of values obtained on previous measurements [10].

All screening projects, including ours, have revealed that women were more likely than men to know their blood pressure [11]. Thus, the awareness of and, consequently, therapy of hypertension was significantly less sufficient in men [11-13]. It might result from the fact that women more frequently seek medical advice, have laboratory tests performed and are more interested in medical issues presented in the mass media.

Only 22\% of the examined Jaworzno inhabitants with arterial hypertension had normal BMI while in $78 \%$ BMI was over 25 . As a comparison, $55 \%$ 
of normotensive participants had normal BMI. Abnormal lipid metabolism was found in as many as 83.2 and $85.2 \%$ of the hypertensive women and men, respectively. It can be concluded that a population with undiagnosed and untreated arterial hypertension mostly comprises obese or overweight individuals with lipid metabolism abnormalities who should therefore undergo regular blood pressure screening. Obesity, which is strongly associated with arterial hypertension, is increasingly recognized as a public health problem.

Numerous investigations have revealed a relationship between BMI and blood pressure; the latter can be markedly affected by weight reduction [14-17]. A bilateral significant correlation was found between BMI $\geq 25 \mathrm{~kg} / \mathrm{m}^{2}$ and the prevalence and severity of arterial hypertension (18). In Poland, the overall percentage of obese/overweight individuals keeps increasing although it differs between Polish Provinces. The lowest proportions of obesity and overweight have been found in Kujawy-Pomerania, West Pomerania and Warmia-Masuria Provinces. The examined sample was recruited in Jaworzno - a city situated in one of Polish industrial regions. It might be presumed that regional lifestyle, cuisine and affluence could increase obesity and overweight rates.
The subgroup with previously undiagnosed and untreated arterial hypertension, and especially its male members, had abnormal glucose levels. This might result from the fact of men less often seeking medical advice.

Considering the limited availability of financial resources intended for preventive health care, there is clear need for the identification of those population categories who should receive particular attention. Our study helped identify a special risk group, i.e., obese or overweight male smokers with lipid metabolism disturbances and positive family history for cardiovascular disease. It is this group who should undergo frequent screening for high blood pressure.

\section{Conclusions}

1. Even $48 \%$ of men and $20 \%$ of women aged between 35 to 55 years of Jaworzno's so far untreated population may have undiagnosed high blood pressure.

2. Obese or overweight men who smoke, exhibit lipid metabolism disturbances and have a family history of cardiovascular disease are quite likely to suffer from undiagnosed arterial hypertension.

\section{Streszczenie}

Wstęp W ramach programu WOBASZ (Wieloośrodkowe Ogólnopolskie Badanie Stanu Zdrowia Ludności) zaobserwowano znaczne zróżnicowanie regionalne w częstości występowania nadciśnienia tętniczego. Niewykluczone, że zróżnicowanie to może wynikać $z$ do tej pory nierozpoznanego nadciśnienia tętniczego. Przedmiotem pracy jest ocena odsetka osób z nierozpoznanym nadciśnieniem wśród mieszkańców Jaworzna oraz charakterystyka tej grupy osób. Materiał i metody List z zaproszeniem do badań wysłano do 1500 mieszkańców będących pod opieką lekarza rodzinnego, do tej pory nie leczonych z powodu chorób układu sercowo-naczyniowego. Do udziału w badaniach zgłosiło się 780 osób, w tym 513 kobiet i 267 mężczyzn w wieku 46,7 \pm 4,3 i 45,6 4 lata. Oceniono ciśnienie tętnicze, BMI, lipidogram i stężenie glukozy, uzyskano informacje odnośnie palenia papierosów, aktywności fizycznej i wywiadu rodzinnego dotyczącego nadciśnienia tętniczego.

Wyniki Nadciśnienie tętnicze stwierdzono u 107 kobiet (21\%) i 128 mężczyzn (47,9\%). Odsetek osób z otyłością i nadwagą wynosił w tej grupie u 76,6\% kobiet i 79,7\% mężczyzn i był znamiennie większy w porównaniu z osobami bez nadciśnienia tętniczego: odpowiednio u 43\% i 51,8\%. Stwierdzono również znamiennie wyższy odsetek osób z nieprawidłowymi wynikami w zakresie gospodarki lipidowej w grupie z nadciśnieniem tętniczym. Odsetek kobiet i mężczyzn z nadciśnieniem, u których stwierdzono przynajmniej jeden nieprawidłowy wynik lipidogramu był porównywalny i wynosił odpowiednio 83,2\% i 85,2\%. Wartości te były znamiennie wyższe niż u normotensyjnych kobiet $(37,8 \%)$ i mężczyzn $(42,4 \%)$.

Wnioski Wśród mieszkańców Jaworzna w wieku 35-55 lat, do tej pory nieleczonych, niezdiagnozowane nadciśnienie tętnicze może występować nawet u $48 \%$ mężczyzn i $21 \%$ kobiet. Najczęściej są to osoby z nadwagą i otyłością.

słowa kluczowe: nadciśnienie tętnicze, otyłość, statystyka, epidemiologia 


\section{References}

1. Januszewicz A. Nadciśnienie tętnicze — zarys patogenezy, diagnostyki i leczenia. Medycyna Praktyczna, Kraków, 2009: 5-15.

2. Walker A. Overweight and hypertension in emerging populations. Am. Heart J. 1996; 468: 581-586.

3. Grabowska H., Grabowski W., Grzegorczyk M. et al. The effect of diet on the risk of primary hypertension development. Dietary recommendations used in the prevention of arterial hypertension. Probl. Pielęg. 2011; 19: 538-544.

4. Europejskie wytyczne dotyczące zapobiegania chorobom serca i naczyń w praktyce klinicznej na 2012 rok. Kardiol. Pol. 2012; 70 (suppl. I): S1-S100.

5. Grodzicki T., Gryglewska B., Tomasik T., Windak A. Zasady postępowania w nadciśnieniu tętniczym. Wytyczne Polskiego Towarzystwa Nadciśnienia Tętniczego oraz Kolegium Lekarzy Rodzinnych w Polsce. Nadciśn. Tẹtn. 2008; 12: 317-342.

6. Suliburska J., Duda G. Palenie papierosów a występowanie nadciśnienia tętniczego u dorosłych. Przeg. Lek. 2006; 63: 864-866.

7. Sayarlioglu H. Rational approaches to the treatment of hypertension: modification of lifestyle measures Kidney Int. Suppl. 2013; 3: 346-348.

8. Zdrojewski T., Bandosz P., Szpakowski P. et al. Rozpowszechnienie głównych czynników ryzyka chorób układu sercowo-naczyniowego w Polsce. Wyniki badania NATPOL PLUS, Kardiol. Pol. 2004; 61: 1-26.

9. Tykarski A., Posadzy-Małaczyńska A., Wyrzykowski B. Rozpowszechnienie nadciśnienia tętniczego oraz skuteczność jego leczenia u dorosłych mieszkańców naszego kraju. Wyniki programu WOBASZ. Kardiol. Pol. 2005; 63: 614-619.

10. Januszewicz A., Prejbisz A. Nadciśnienie tętnicze. In: Szczeklik A., Gajewski P. (ed.). Interna Szczeklika. Podręcznik chorób wewnętrznych. Medycyna Praktyczna, Kraków 2014; 411-421.

11. Zdrojewski T. Prevalence and awareness of arterial hypertension in Poland and in the world. Post. Nauk Med. 2011; 3: 2-10.

12. Antikainen R.L., Moltchanov V.A., Chukwuma C. et al. Trends in the prevalence, awareness, treatment and control of hypertension: the WHO MONICA Project. Eur. J. Prev. Cardiol. 2006; 13: 13-29.

13. Zdrojewski T., Szpakowski P., Bandosz P. et al. Arterial hypertension in Poland in 2002. J. Hum. Hypertens. 2004; 18: 557-562.

14. Chrostowska M., Szyndler A., Polonis K. et al. Nadciśn. Tętn. 2011; 15: 155-162.

15. Sonne-Holm S., Sørensen T. I., Jensen G., Schnohr P. Independent effects of weight change and attained body weight on prevalence of arterial hypertension in obese and non-obese men. BMJ. 1989; 299: 767-770.

16. Rahmouni K., Correia M.L., Haynes W.G., Mark A.L. Obesity-Associated Hypertension. New Insights Into Mechanisms. Hypertension 2005; 45: 9-15.

17. Hall J. The Kidney Hypertension, and Obesity. Hypertension 2003; 41: 625-633.

18. Szczepaniak-Chicheł L., Mastej M., Jóźwiak J. et al. Występowanie nadciśnienia tętniczego w zależności od masy ciała w populacji polskiej - badanie LIPIDOGRAM 2004. Nadciśn. Tętn. 2007; 11: 195-204. 